\title{
Decline in lichen biodiversity on oak trunks due to urbanization
}

\author{
Håkan Lättman, Karl-Olof Bergman, Malin Rapp, Malin Tälle, Lars Westerberg and Per \\ Milberg
}

\section{Linköping University Post Print}

\section{Tweet}

N.B.: When citing this work, cite the original article.

Original Publication:

Håkan Lättman, Karl-Olof Bergman, Malin Rapp, Malin Tälle, Lars Westerberg and Per Milberg, Decline in lichen biodiversity on oak trunks due to urbanization, 2014, Nordic Journal of Botany, (32), 4, 518-528.

http://dx.doi.org/10.1111/j.1756-1051.2013.00413.x

Copyright: Wiley

http://eu.wiley.com/WileyCDA/

Postprint available at: Linköping University Electronic Press

http://urn.kb.se/resolve?urn=urn:nbn:se:liu:diva-109110 


\section{Decline in lichen biodiversity on oak trunks due}

\section{to urbanization}

Håkan Lättman, Karl-Olof Bergman, Malin Rapp, Malin Tälle, Lars Westerberg and Per

Milberg

Håkan Lättman, IFM Biology, Conservation Ecology Group, Linköping University, SE-581

83 Linköping, Sweden, and School of Life Sciences, Södertörn University, SE-181 49

Huddinge, Sweden

Karl-Olof Bergman, Malin Rapp, Malin Tälle, Lars Westerberg, Per Milberg, IFM Biology,

Conservation Ecology Group, Linköping University, SE-581 83 Linköping, Sweden

Correspondence: per.milberg@liu.se 
Abstract: Biodiversity often suffers from urbanization. In the present study, we focused on how the length of urbanization affects the richness of 17 epiphytic lichen species and their cover on large oaks in urban environments in a city of 100000 inhabitants in SE Sweden. We also surveyed trees in adjacent rural areas, selected to have similar distributions of tree trunk circumference and surrounding oak density (within $300 \mathrm{~m}$ ). Lichen richness and cover were lower on urban trees compared to rural trees. Furthermore, richness and cover decreased with the length of time that urban trees had been surrounded by houses. Most of the species that were analysed demonstrated a decline in occurrence with respect to the duration of housing development. The reduction in the probability of occurrence varied from $60 \%$ (Calicium viride, Evernia prunastri), 80\% (Chrysothrix candelaris) to 90\% (Ramalina spp. Ach.) during the 160 -year period of urbanization considered. Therefore, even if valuable trees survive over the course of development, their lichen biota is likely to become depleted over time.

Key words: housing; landscape; lichens; Quercus; spatial; Sweden; urbanization 


\section{Introduction}

Urbanization alters the natural environment in a number of ways and causes local extinction of species (McKinney, 2006). Urbanization is considered to be one of the worst threats to endangered species (Czech et al. 2000). Many studies have shown that when moving from rural areas to the central parts of a city, there is a gradual decrease in species richness in a number of organismal groups, such as butterflies (Blair and Launer 1997; Blair 1999), beetles (Ishitani et al. 2003; Niemelä and Kotze 2009; Su et al. 2011), birds (Blair 1999; Gagne and Fahrig 2011), amphibians (Price et al. 2006; McKinney 2008), reptiles (McKinney 2008), mammals (McKinney 2008), and plants (McKinney 2008). In contrast, there are a few studies that show that urbanization has no effect on biodiversity. For instance, Carabidae assemblages showed no changes across urban gradients in three cities in Finland, Bulgaria and Canada with three different levels of urbanization (Niemelä et al. 2002). A study in the lower Florida Keys concluded that the native ant fauna were not, at the moment, negatively affected by length of urbanization (Forys and Allen 2005). Nevertheless, with a few exceptions, urbanization generally seems to reduce biodiversity.

Urbanization affects various environmental factors that in turn affect survival and reproduction of species. The mechanisms involved in species loss varies, spanning from habitat loss and fragmentation (Robinson et al. 2005) to assumed shifts in biotic interactions and possible adverse effects of pollution (Tarhanen et al. 2000). One group that is particularly sensitive to pollution is lichens. In urban areas, sulphur and nitrogen oxides $\left(\mathrm{SO}_{\mathrm{x}}, \mathrm{NO}_{\mathrm{x}}\right)$ primarily cause the greatest damage to lichens (Giordani 2007). Over the last century, air pollution in urban areas has been subject to substantial changes, both in composition and quantity (e.g. Fenger 2009; Agnan et al. 2013), which is probably a main driver for the changes documented for the urban lichen flora (e.g. Munzi et al. 2007; Lisowska 2011). 
Lichens also have different tolerances and preferences for substrates. Some lichens are restricted to large trees (Washburn and Culley 2006) that usually have a coarse bark structure. Such specialised lichens have declined as the density of that substrate has diminished due to agriculture and forestry (Hedenås and Ericson 2008; Belinchón et al. 2009). However, trees are often an important feature of cities and are often allowed to grow old for a number of reasons, including human well being, economic value, aesthetics, shade production, and in some circumstances, fire prevention (Lohr et al. 2004; Donovan and Butry 2010, 2011). An example is the large number of Quercus robur L. trees, which have been maintained throughout urbanization, in urban Linköping, a city with 100000 inhabitants in southeastern Sweden. Mobile organisms can escape urban habitats, while trees (and lichens) are inevitably incorporated into the urban environment. Lichens on the remaining trees are thus isolated, and their dispersal and establishment may be negatively affected. However, the future prospects for epiphytic organisms are better than those of many other elements of urban biodiversity as trees will continue to be an important feature of cityscapes.

In the present study, a selection of lichen species were surveyed on $Q$. robur trees in urban and rural environments. The objectives of this study can be divided into four questions: Is there any difference with regard to (i) species richness and (ii) cover of epiphytic lichens on Q. robur in urban or rural environment? How are (iii) species richness and (iv) cover of epiphytic lichens on $Q$. robur affected by the length of urbanization? To make these comparisons, we matched a population of urban oaks with a selection of rural oaks based on tree circumference and the density of surrounding oaks because oak lichens are sensitive to both the size of their host tree (Johansson et al. 2009) and the density of surrounding oaks (Westerberg, Muhammadi, Bergman and Milberg unpublished data). 


\section{Materials and Methods}

\section{Study area}

The study was conducted in the city of Linköping and surrounding rural areas south of the city, in the province of Östergötland, Sweden (Fig. 1). The area north of Linköping municipality was avoided due to differences in soil and vegetation characteristics from the urban areas. The area is located at an altitude of 30 to $125 \mathrm{~m}$ above sea level and consists of the urban city centre of Linköping, urban district and surrounding rural environments. The city of Linköping is the seventh largest city in Sweden with a population of 104232 in 2010 (Linköpings kommun 2011). It was founded in the $11^{\text {th }}$ Century, but the majority of buildings have been built since the mid-1800s. The annual average temperature at the nearest meteorological station (urban district Malmslätt) is $6 \cdot 1^{\circ} \mathrm{C}$, with an average temperature of $3 \cdot 2{ }^{\circ} \mathrm{C}$ in January and $16 \cdot 2{ }^{\circ} \mathrm{C}$ in July; and the average precipitation is $516 \mathrm{~mm}$ per year (Statistics Sweden 2011). Linköping has expanded concentrically (Fig. 2), and the city centre consists largely of three to five storey buildings with shops at the street level. Blocks with flats and one to two-storey houses make up the greater part of the residential areas in the urban district. Squares, parks and paved roads are both in the city centre and urban district. The surrounding rural areas consist mainly of a mixed landscape with deciduous forests, planted conifers, arable land and pastures.

\section{Selection of Quercus robur and lichen species}

We studied the lichen flora on pedunculate oak (Quercus robur). Quercus robur is common in and around Linköping, and urban trees were selected for study from an existing tree database. The database contains the position and circumference of all large $Q$. robur, as well as several other tree species in the province of Östergötland, and was developed by the County Administration Board in Linköping (available at http://gis.lst.se/lstgis/). Using 
ArcMap 9.3 (ESRI, 2011), all Q. robur within the municipality of Linköping with a circumference $>250 \mathrm{~cm}$ were chosen because these trees can be assumed to be old enough to host a high diversity of lichen species (e.g., Johansson et al. 2009). The age of the sampled trees can be estimated from dendrological studies in the area (Berg 2006) to be at least 180 to 240 years; therefore, most trees included would have established 100-150 yrs before the onset of urbanization. A $250 \mathrm{~m}$ by $250 \mathrm{~m}$ grid was added over the urban area, and in each cell in the grid where $Q$. robur trees were present, the oak tree closest to the centre of the cell was chosen. This meant that the minimum distance between included tress were at least $250 \mathrm{~m}$. From the database, we selected 105 urban trees, which were matched with a population of rural trees (Fig. 1). The criteria for matching urban trees with rural trees were that (i) the distribution of trunk circumference and (ii) the density of trees within $302 \mathrm{~m}$ should be similar. Some selected rural trees were excluded during the fieldwork because they had been cut down, or were in private gardens; others were substituted with similarly sized trees for the same reasons. In the end, we used 105 and 109 trees in urban and rural environments respectively.

The seventeen lichen species selected for our survey are shown in Table 1 together with their red-list category (Gärdenfors 2005) and, when appropriate, if the species are used as an indicator species for forests of conservation value (Nitare 2010), as well as with substrate preference (Santesson et al. 2004). Species were selected to represent relatively easily identified species, or a group of species within a genus (in two cases when it was difficult to accurately identify to species level), that are either habitat specialists or common and widespread. The nine common species occur more or less throughout all of Sweden, and some of them are considered resistant to air pollutants. The eight rare lichens are red-listed by the threat categories near threatened (NT) or vulnerable (VU), and/or are indicator species for high nature conservation and are thought to be sensitive to air pollution. Two additional 
lichen species were initially included but were excluded at the beginning of the fieldwork as they proved too difficult to reliably identify in the field. After finishing fieldwork it turned out that three species (Calicium quercinum Pers., Lecanographa amylacea (Ehrh. ex Pers.) Egea \& Torrente and Schismatomma decolorans (Turner \& Borrer ex Sm.) Clauzade \& Vezda in Vezda) had not been found.

\section{Field survey}

The fieldwork was conducted during April, May, October and November, 2011. For every oak, circumference at breast height was measured to the nearest centimetre. The depth of tree trunk bark crevices was measured on the north, east, south and west sides of the trunk to the nearest millimetre. Based on these four measurements, a mean bark crevice depth was

calculated for each tree. Sun exposure was estimated by assessing how much sun in percent to the trunk was received, taking into account the shade cast by nearby buildings, shrubs and trees. On each tree trunk, lichens were examined from 50 to $150 \mathrm{~cm}$ above the ground; the bottom of the trunk was avoided because they varied greatly between individual trees. For each of the target lichen species, covered was estimated to the nearest $\mathrm{cm}^{2}$ and expressed as a percentage of the inspected trunk area.

\section{Additional parameters}

Some complementary explanatory variables were also considered (Table 2). The number of Q. robur trees around each tree, including the tree being examined, was used as an explanatory variable. Six different radii were used: 150, 250, 350, 500, 700 and $1000 \mathrm{~m}$. The same range of radii was also used to determine the area of buildings around each studied $Q$. robur. The data on buildings were drawn from the GSD-Topographic Map (Lantmäteriet, CLantmäteriet license number I2012/0021) and combined four different classes of buildings (industrial buildings, one and two storey houses, apartment buildings and city blocks). Length 
of urbanization was estimated from the average year of construction of the five buildings closest to the target tree, using a radius of approximately $200 \mathrm{~m}$ (data from the municipality of Linköping). Fewer buildings were used if the year of construction was not available for all five buildings or if fewer than five buildings were within $200 \mathrm{~m}$ of the tree. For the city centre (Fig. 2), where some older buildings have been demolished and replaced with newer ones, the above approach would underestimate the age. We therefore assigned the age 1900 to seven buildings that were erected by 1950 or later (hence replacing older buildings). One tree associated with buildings in the area dated to the eighteenth century (Fig. 2) was given the age 1850. In total, these age assignments affected the urban length estimates of eight trees in the city centre, and are most likely underestimates of the true ages.

\section{Statistical analyses}

The number of urban and rural trees of $Q$. robur used in the statistical analyses was 105 and 109, respectively, and in total, 14 lichen taxa were observed: nine common and five rare.

To evaluate the data, regression analyses (generalised linear model, GLM) were run in Statistica 10 (Statsoft 2011). The first set of analyses involved the number of target species per tree on urban vs. rural trees (normal distribution; identity link), and the total cover of the target lichens per tree for urban vs. rural trees (normal distribution; log link). Rural trees were not included in any further analyses.

The second set of analyses evaluated the relationship between (i) the number of target species per tree (normal distribution; identity link), and (ii) the total cover of target lichen per tree (normal distribution; log link), as related to number of years in an urban setting (i.e., the average age of the five closest buildings).

The third set of analyses involved the species-wise occurrence of the eight most frequent species (binomial distribution; logit link). For each radius (150-1000 m), a model was made and included the following candidate explanatory variables: (i) length of urbanization, (ii) tree 
circumference, (iii) average bark crevice depth, (iv) sun exposure, (v) density of oaks, and (iv) cover of buildings. Using Akaike information criterion (AIC), explanatory variables, including radii, were selected. Depth of bark crevices was chosen as it is often considered a better proxy for tree age than is tree circumference (Barkman 1958; Pedersen 1980; see Johansson et al. 2009). However, as the depth and circumference were poorly correlated, both were considered as candidate variables. Tree circumference and density of oaks were log transformed before the analysis.

Finally, six attributes of the fourteen species were analysed in relation to their average

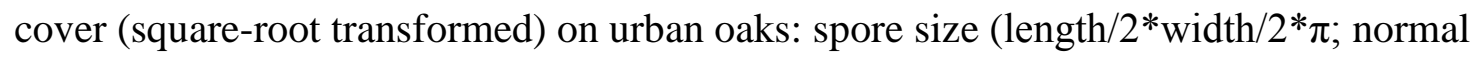
distribution; identity link function); diaspores (binomial; logit); growth form and photobiont (multinomial; logit); spores and pycnidium (ordinal multinomial; logit).

\section{Results}

In total, 214 trees of Quercus robur were studied, of which 105 and 109 were in urban and rural environments, respectively. Of the 17 lichen species included in the study, three rare and red-listed species (Calicium quercinum, Lecanographa amylacea and Schismatomma decolorans) were not found (Table 1). The number of lichen species per tree varied between 0 and 9. The total number of observations of lichen species was 954, with 400 observations in urban areas and 554 in rural areas.

\section{Species richness and cover: urban vs. rural}

There were clear differences in the occurrence and cover of individual lichen species between the urban and rural areas (Fig. 3). Four taxa were found only in the rural areas (Calicium adspersum Pers., Cyphelium inquinans (Sm.) Trevis., Sclerophora coniophaea (Norman) J. Mattsson \& Middelb. in Middelb. \& J. Mattsson and Usnea spp. Dill. ex Adans.). 
All taxa, except Lepraria incana (L.) Ach., occurred more frequently on rural oaks than on urban oaks (Fig. 3a). All taxa (including Lepraria incana) had a higher cover on rural than urban oaks, both when looking at averages over all trees (including zero cover observations) and when considering only trees on which lichens were present (Fig. 3b and c).

The number of target species per tree and the cover of target lichens were significantly higher on oaks in rural environments than on oaks in the urban area $(\mathrm{P}<0.0001$ in both cases $)$ (Fig. $4 \mathrm{a}$ and c). Mean species richness was $34 \%$ higher on rural oaks than urban oaks $(5 \cdot 1$ and 3.8 lichen species, respectively) (Fig. 4a). When looking at the total cover of the 14 species, the differences between urban oaks and rural oaks were even more pronounced, with a mean cover many times higher on rural versus urban oaks $(0.041 \%$ and $0.007 \%$, respectively) (Fig. 4c).

\section{Species richness and cover: effects from length of urbanization}

The number of species per tree decreased significantly with the increasing age of the surrounding buildings ( $\mathrm{P}=0.00031)$ (Fig. 4b). The average number of target species in the most recently urbanized areas was four times higher than in the oldest areas (Fig. 4b), and a similar decline was found in the cover of target lichens (Fig. 4d).

\section{Species-wise responses to environmental factors in urban areas}

Out of the 14 species, eight were sufficiently frequent to be analysed individually in consideration of all explanatory variables. The selected models proved significant for seven of the eight species (Table 3). The majority of the species were affected by urbanization factors or oak size factors, while few species were affected by the other biotic factors such as oak density. The length of urbanization had a significant negative effect on five species and the area covered by buildings on two species. Chrysothrix candelaris (L.) J. R. Laundon and Hypogymnia physodes (L.) Nyl. were positively affected by the area covered by buildings 
(Table 3). Species responded mostly to area covered by buildings at larger scales, $\geq 350 \mathrm{~m}$. A higher tree circumference or deeper bark crevices had a significant positive effect on the occurrence of four species and a negative effect on one. Sun exposure had a significant negative impact on two species (Table 3). Oak density significantly affected only one species negatively and none positively.

For the four species where the length of urbanization significantly affected their occurrence, separate binomial (logit link) GLMs were conducted. All species showed a decrease in prevalence in the older parts of the city in comparison to newer areas. The models predicted a reduction of $60 \%$ (Calicium viride Pers., Evernia prunastri (L.) Ach.), 80\% (Chrysothrix candelaris) and 90\% (Ramalina spp.) probability of occurrence during the 160 years of urbanization (Fig. 5).

Out of the six tested species attributes (Table 4), only one had a significant association with cover on urban trees: 'spores', i.e., to what extent a species relies on spore dispersal for reproduction $(\mathrm{P}=0 \cdot 039)$.

\section{Discussion}

This study showed a clear reduction in species richness and cover on oaks in urban versus rural areas. Likewise, the length of urbanization reflects the same pattern, a finding that is consistent with studies of other organismal groups (Blair and Launer 1997; Blair 1999; Ishitani et al. 2003; Price et al. 2006; McKinney 2008; Niemelä and Kotze 2009; Gagne and Fahrig 2011; Su et al. 2011; Coffey and Fahrig 2012). Our results also support that dispersal mode may be an important factor in predicting which lichen species are affected by urbanization. 


\section{Lower richness and cover on urban oaks}

Species in urban areas are affected by a complex interaction between factors, such as pollution, temperature, moisture, disturbance and habitat configuration (McDonnell et al. 1997). Generally habitat loss and fragmentation are among the most important factors in urban areas (McKinney 2006; Niemelä 1999), which for most species is negative. A high density of large oak trees has proved to be important for species richness and the occurrence of some lichens (e.g. Paltto et al. 2010), and shows that habitat configuration (or connectivity) is important (Coffey and Fahrig 2012). The sample populations of urban and rural oaks were matched for both circumference and surrounding tree density, thereby allowing for comparison while controlling for habitat quality (circumference) and connectivity. Several species are generalists and not confined to oaks, but because previous studies emphasized the importance of oaks (Paltto et al. 2010; Westerberg, Muhammadi, Bergman and Milberg, unpublished), we argue that our sample design can control for differences in habitat connectivity. Thus, by controlling for habitat length and habitat composition (density of surrounding oaks), we were able to isolate the effects of urbanization, from that of a general decrease in habitat. In cases where it was possible to analyse species, our study showed that urbanization had a clear effect on cover (Table 3). The explanatory variable, i.e., length of urbanization, showed that five species were negatively affected, while area covered by buildings showed that three species were negatively affected and one species was positively affected.

A factor we did not control for was air and dust pollution. Lichen declines in urban environments were reported very early with the industrialisation of Europe (Grindon 1859; Nylander 1866). The main factor for the decline was $\mathrm{SO}_{\mathrm{x}}$ generated by industries and traffic (Gilbert 1968). SO $\mathrm{S}_{\mathrm{x}}$ peaked during the 1960s and 1970s, and lichen deserts in urban areas were reported at elevated emission levels (Hawksworth and Rose 1970). However, air quality 
has recently improved in many urban areas (Lisowska 2011, Lackovicova et al. 2013). In Tampere, Finland, sulphur dioxide levels were reduced from $160 \mu \mathrm{g} \mathrm{m}^{-3}$ in 1973 to $2 \mu \mathrm{g} \mathrm{m}^{-3}$ in 1999, which coincided with an increase in the richness of lichen epiphytes and their cover since 1980 (Ranta 2001). For the municipality of Linköping, $\mathrm{SO}_{\mathrm{x}}$ decreased with $85 \%$ and $\mathrm{NO}_{\mathrm{x}}$ with $60 \%$ from 1990 to 2010 (RUS 2013). The improvement in the local lichen flora is supported by our research as shown by the fact that there were no differences between the number of oaks without target species in urban and rural areas (4 out of 105 urban oaks without target lichens and 3 of 109 rural oaks). However, there were nevertheless large differences in species diversity and the cover of individual species between urban and rural oaks. Our results show that species that disperse by spores were often absent or had low cover, while those that were vegetative dispersed were among those with the highest cover (Table 4). Species dependent on the process of re-lichenisation involving contact between spores and an appropriate photobiont, after successful dispersal, seem less likely to succeed in urban areas. The species most sensitive to urbanization in our study all belong to this group. Calicium adspersum, Cyphelium inquinans, Sclerophora coniophaea and Usnea spp. were not found on oaks in the urban environment, but were present in the rural environment. Calicium adspersum, C. inquinans and S. coniophaea are classified as indicators of forest areas with high conservation values (Nitare 2010), while Usnea spp. are known to be sensitive to air pollution (Hawksworth and Rose 1970). In addition to the dispersal mode, the photobiont may be important. Tarhanen et al. (2000) demonstrated that the green alga Trebouxia is sensitive to air pollution. Their results showed that high concentrations of air pollutants increased plasmolysis and mitochondrial changes in cells. Furthermore, degenerated cells showed altered chloroplasts and electron-translucent pyrenoglobuli as far as 35 to $50 \mathrm{~km}$ from the pollutant source. Low lichen cover on many urban oaks compared to rural oaks suggests that something is having a negative effect on lichens in urban areas, even though the air quality 
has improved. Armstrong and Bradwell (2010) reviewed 52 studies with reported growth rates for crustose lichens, and 33 of the surveys had been performed in Europe. If we adopt an average European radial growth rate of $0.92 \mathrm{~mm}$ per year, which seems reasonable, lichen thalli would need 6 years to reach one centimetre in diameter and thus become clearly visible to the naked eye. Of the five foliose and fruticose lichens, growth rates are available for Hypogymnia physodes: approximately 3 to $5 \mathrm{~mm}$ in diameter per year (Gorbach and Kobzar 1981; unpublished data), with a corresponding shorter time to reach visibility. Given that levels of sulphur and nitrogen dioxides have steadily decreased over the last 30 years, there should have been ample time for regrowth for most lichens, assuming that they are not dispersal or photobiont limited and that current $\mathrm{SO}_{\mathrm{x}}$ and $\mathrm{NO}_{\mathrm{x}}$ levels are sufficiently low.

Another potentially important factor is the higher temperature/lower humidity in urban areas. Lichens are known to be sensitive to changes in temperature such as might be seen with global warming (van Herk et al. 2002). Most lichen species also seem to favour moist conditions in urban areas (Coffey and Fahrig 2012). Therefore, shifts in temperature and moisture might be limiting to urban lichens. Several studies have shown that temperatures are generally higher in urban versus rural areas (George et al. 2007; Bulut et al. 2008; Liu et al. 2009), a phenomena known as the "urban heat island effect". Hughes (2006) investigated the "urban heat island effect" in four cities in the United Kingdom of varying population size. Norwich had on average urban temperatures $0 \cdot 5^{\circ} \mathrm{C}$ higher than surrounding rural areas. Because the population size of Norwich is similar to Linköping's, we can assume the latter has a similar temperature difference. Relative humidity $(\mathrm{RH})$ is, to a large extent, a function of temperature, so we would expect the urban heat island effect to coincide with lower RH. Furthermore, hard surfaces, efficient canalisation of runoff water, and small volumes of vegetation (low evapotranspiration) in urban areas also suggest lower RH values. 
Nevertheless, the data are conflicting (George et al. 2007 found no differences, while Liu et al. 2009 did).

\section{Loss rate over the course of urbanization}

Numerous studies have investigated how a spatial gradient from rural, suburban to urban areas affects the diversity and abundance of organisms. Most studies have concluded that the number of species and their abundance generally decreases with increasing urbanization (Mercado Cárdenas and Buddle 2009), but there are exceptions particularly when invasive species are involved (Dolan et al. 2011) and generalist (Magura et al. 2008; Tóthmérész et al. 2011). The same reduction in species and their abundance toward the city centre can also be observed in temporal studies. For instance, Fattorini (2012) reconstructed the extinction trends of four insect groups in urban Rome, Italy from 1885-1999. Her results showed a clear decline in species richness in each group of insects. Price et al. (2006) examined the incidence of species from the vertebrate family Salamandridae near Davidson, North Carolina, USA, for a period of 30 years and found that the populations declined over time.

Our results showed a clear effect on species number and cover of lichens with the increasing length of urbanization. Of all 14 lichens, eight were analysed individually (Table 3). Length of urbanization, or the area covered by buildings around the trees, affected seven species negatively. We estimated a decrease in species richness and the total cover of target lichen species per tree (Fig. $4 \mathrm{~b}$ and $4 \mathrm{~d}$ ) and a lowering probability of occurrence by $3.7-5.6 \%$ per decade depending on lichen species (Figure 5). In summary, the relatively slow but steady loss of biodiversity confirms the assumption of Hahs et al. (2009) that modern cities potentially carry a large extinction debt; however, the interpretation is complicated by the return of lichens following recent improvements in air quality (see above). 


\section{Conclusions}

We have shown major differences in lichen species richness and cover between urban and rural environments, as well as a clear decrease with the length and degree of urbanization on remnant large oaks in a city. Therefore, even if the prospects are good for a continuous supply of epiphytic substrate in cities - where trees are likely to exist - their value for epiphytic lichens seems limited. For the urban planner, this means two things. First, retaining valuable individual trees during urbanization does not automatically contribute to lichen biodiversity. Second, the preservation of lichen biodiversity is most likely best achieved if urban development leaves large contiguous areas of trees with rich lichen populations intact with plans for connecting fragments of old trees instead of embedding them within densely urbanized areas.

\section{Acknowledgements}

We are indebted to Lena Samuelsson and Linköping municipality for assistance with obtaining maps of Linköping's different urban district boundaries and the age of buildings.

\section{References}

Agnan, Y. Séjalon-Delmas, N., Probst, A. 2013. Comparing early twentieth century and present-day atmospheric pollution in SW France: A story of lichens. - Environmental Pollution 172: 139-148.

Armstrong, R. and Bradwell T. 2010. Growth of crustose lichens: a review. - Geografiska Annaler Series A Physical Geography 92: 3-17.

Barkman, J. J. 1958. Phytosociology and ecology of cryptogamic epiphytes: including a taxonomic survey and description of their vegetation units in Europe. - Assen, Van Gorcum. 
Belinchón, R., Martínez, I., Otálora, M. A. G., Aragón, G., Dimas, J. and Escudero, A. 2009. Fragment quality and matrix affect epiphytic performance in a Mediterranean forest landscape. - American Journal of Botany 96: 1974-1982.

Berg, N. 2006. Age and size of hollow oaks and their associated lichen flora and beetle fauna. - Final thesis, Linköping University, LiTH-IFM- Ex--05/1605--S.

Blair, R. B. 1999. Birds and butterflies along an urban gradient: surrogate taxa for assessing biodiversity? - Ecological Applications 9: 164-170.

Blair, R. B. and Launer, A. E. 1997. Butterfly diversity and human land use: species assemblages along an urban gradient. - Biological Conservation 80: 113-125.

Bulut, Y., Toy, S., Irmak, M. A., Yilmaz, H. and Yilmas, S. 2008. Urban-rural climatic differences over a 2-year period in the city of Erzurum, Turkey. - Atmósfera 21: 121133.

Coffey, H. M. P. and Fahrig, L. 2012. Relative effects of vehicle pollution, moisture and colonization sources on urban lichens. - Journal of Applied Ecology 49: 1467-1474.

Czech, B., Krausman, P. R. and Devers, P. K. 2000. Economic associations among causes of species endangerment in the United States. - BioScience 50: 593-601.

Dolan, R. W., Moore, M. E. and Stephens, J. D. 2011. Documenting effects of urbanization on flora using herbarium records. - Journal of Ecology 99: 1055-1062.

Donovan, G. H. and Butry, D. T. 2010. Trees in the city: valuing street trees in Portland, Oregon. - Landscape and Urban Planning 94: 77-83.

Donovan, G. H. and Butry, D. T. 2011. The effect of urban trees on the rental price of singlefamily homes in Portland, Oregon. - Urban Forestry \& Urban Greening 10: 163-168.

ESRI. 2011. ArcGIS Desktop: Release 10. - Redlands, CA: Environmental Systems Research Institute. 
Fattorini, S. 2012. Insect extinction by urbanization: a long term study in Rome. - Biological Conservation 144: 370-375.

Fenger, J. 2009. Air pollution in the last 50 years: From local to global. - Atmospheric Environment 43: 13-22.

Forys, E. A. and Allen, C. R. 2005. The impacts of sprawl on biodiversity: the ant fauna of the lower florida keys. - Ecology and Society 10(1): 25. [online] URL: http://www.ecologyandsociety.org/vol10/iss1/art25/.

Gagne, S. A. and Fahrig, L. 2011. Do birds and beetles show similar responses to urbanization? - Ecological Applications 21: 2297-2312.

George, K., Ziska, L. H., Bunce, J. A. and Quebedeaux, B. 2007. Elevated atmospheric $\mathrm{CO}_{2}$ concentration and temperature across an urban-rural transect. - Atmospheric Environment 41: 7654-7665.

Gilbert, O. L. 1968. Bryophytes as indicators of air pollution in the Tyne Valley. - New Phytologist 67: 15-30.

Giordani, P. 2007. Is the diversity of epiphytic lichens a reliable indicator of air pollution? A case study from Italy. - Environmental Pollution 146: 317-323.

Gorbach, N V. and Kobzar, N. N. 1981. Determination of the age of epiphyte lichen Hypogymnia physodes (L.) Nyl. - Doklady Akademii Nauk BSSR [Minsk] 25: 848-851.

Grindon, L. H. 1859. The Manchester flora. - W. White, London.

Gärdenfors, U. ed 2005. Rödlistade arter i Sverige 2005 (The 2005 red list of Swedish species). ArtDatabanken, SLU, Uppsala. [in Swedish]

Hahs, A. K., McDonnell, M. J., McCarthy, M. A., Vesk, P. A., Corlett, R. T., Norton, B. A., Clemants, S. E., Duncan, R. P., Thompson, K., Schwartz, M. W. and Williams, N. S. G. 2009. A global synthesis of plant extinction rates in urban areas. - Ecology Letters 12: $1165-1173$. 
Hawksworth, D. L. and Rose, F. 1970. Qualitative scale for estimating sulphur dioxide pollution in England and Wales using epiphytic lichens. - Nature 227: 145-148.

Hedenås, H. and Ericson, L. 2008. Species occurrences at stand level cannot be understood without considering the landscape context: cyanolichens on aspen in boreal Sweden. Biological Conservation 141: 710-718.

Hughes, K. 2006. The impact of urban areas on climate in the UK: a spatial and temporal analysis, with an emphasis on temperature and precipitation effects. - Earth \& Environment 2: 54-83.

Ishitani, M., Kotze, D. J. and Niemelä, J. 2003. Changes in carabid beetle assemblages across an urban-rural gradient in Japan. - Ecography 26: 481-489.

Johansson, V., Bergman, K.-O., Lättman, H. and Milberg, P. 2009. Tree and site quality preferences of six epiphytic lichens growing on oaks in southeastern Sweden. - Annales Botanici Fennici 46: 496-506.

Lackovicova, A., Guttova, A., Backor, M., Pisut, P. and Pisut, I. 2013. Response of Evernia prunastri to urban environmental conditions in Central Europe after the decrease of air pollution. - The Lichenologist 45: 89-100.

Linköpings kommun. 2011. Linköpings kommun, Statistik \& utredningar, Statistikinfo 2011:7. [in Swedish]

Lisowska, M. 2011. Lichen recolonisation in an urban-industrial area of southern Poland as a result of air quality improvement. - Environmental Monitoring \& Assessment 179: 177190.

Liu, W., You, H. and Dou, J. 2009. Urban-rural humidity and temperature differences in the Beijing area. - Theoretical \& Applied Climatology 96: 201-207. 
Lohr, V. I., Pearson-Mims, C. H., Tarnai, J. and Dillman, D. A. 2004. How urban residents rate and rank the benefits and problems associated with trees in cities. - Journal of Arboriculture 30: 28-35.

Magura, T., Tóthmérész, B. and Molnár, T. 2008. A species-level comparison of occurrence patterns in carabids along an urbanisation gradient. - Landscape and Urban Planning 86: 134-140.

McDonnell, M. J., Pickett, S. T. A., Groffman, P., Bohlen, P., Pouyat, R. V., Zipperer, W. C., Parmelee, R. W., Carreiro, M. M. and Medley, K. 1997. Ecosystem processes along an urban-to-rural gradient. - Urban Ecosystems 1: 21-36.

McKinney, M. L. 2006. Urbanization as a major cause of biotic homogenization. - Biological Conservation 127: 247-260.

McKinney, M. L. 2008. Effects of urbanization on species richness: a review of plants and animals. - Urban Ecosystems 11: 161-176.

Mercado Cárdenas, A. and Buddle, C. M. 2009. Introduced and native ground beetle assemblages (Coleoptera: Carabidae) along a successional gradient in an urban landscape. - Journal of Insect Conservation 13: 151-163.

Munzi, S., Ravera, S. and Caneva, G. 2007. Epiphytic lichens as indicators of environmental quality in Rome. - Environmental Pollution 146: 350-358.

Niemelä, J. 1999. Is there a need for a theory of urban ecology? - Urban Ecosystems 3: 57-65.

Niemelä, J. and Kotze, D. J. 2009. Carabid beetle assemblages along urban to rural gradients: a review. - Landscape and Urban Planning 92: 65-71.

Niemelä, J., Kotze, D. J., Venn, S., Penev, L., Stoyanov, I., Spence, J., Hartley, D. and de Oca, E. M. 2002. Carabid beetle assemblages (Coleoptera, Carabidae) across urban-rural gradients: an international comparison. - Landscape Ecology 17: 387-401. 
Nitare, J. 2010. Signalarter. Indikatorer på skyddsvärd skog. Flora över kryptogamer (4th ed.) (Indicators for valuable forest areas. A cryptogam flora). - Jönköping: Skogsstyrelsen. [in Swedish]

Nylander, W. 1866. Les lichens du Jardin du Luxembourg. - Bulletin de la Société Botanique de France 13: 364-372. [in French]

Paltto, H., Thomasson, I. and Nordén, B. 2010. Multispecies and multiscale conservation planning: setting quantitative targets for red-listed lichens on ancient oaks. Conservation Biology 24: 758-768.

Pedersen, I. 1980. Epiphytic lichen vegetation in an old oak wood, Kaas skov. - Botanisk Tidsskrift 75: 105-120.

Price, S. J., Dorcas, M. E., Gallant, A. L., Klaver, R. W. and Willson, J. D. 2006. Three decades of urbanization: estimating the impact of land-cover change on stream salamander populations. - Biological Conservation 133: 436-441.

Ranta, P. 2001. Changes in urban lichen diversity after a fall in sulphur dioxide levels in the city of Tampere, SW Finland. - Annales Botanici Fennici 38: 295-304.

Robinson, L., Newell, J. P. and Marzluff, J. M. 2005. Twenty-five years of sprawl in the Seattle region: growth management responses and implications for conservation.Landscape \& Urban Planning 71: 51-72.

RUS. 2013. Regional utveckling och samverkan i miljömålssystemet. Nationella emissionsdatabasen. http://www.rus.lst.se/nyheter.html. [in Swedish]

Santesson, R., Moberg, R., Nordin, A., Tønsberg, T. and Vitikainen, O. 2004. Lichen-forming and lichenicolous fungi of Fennoscandia. - Museum of Evolution, Uppsala University, Uppsala.

Statistics Sweden. 2011. Statistisk årsbok för Sverige 2011 (Statistical yearbook of Sweden 2011). - Official statistics of Sweden, Örebro. [in Swedish] 
Statsoft. 2011. STATISTICA (Data Analysis Software System), Version 10. www.statsoft.com.

Su, Z., Zhang, R. and Qiu, J. 2011. Decline in the diversity of willow trunk-dwelling weevils (Coleoptera: Curculionoidea) as a result of urban expansion in Beijing, China. - Journal of Insect Conservation 15: 367-377.

Tarhanen, S., Poikolainen, J., Holopainen, T. and Oksanen, J. 2000. Severe photobiont injuries of lichens are strongly associated with air pollution. - New Phytologist 147: 579590.

Tóthmérész, B., Máthé, I., Balázs, E. and Magura, T. 2011. Responses of carabid beetles to urbanization in Transylvania (Romania). - Landscape \& Urban Planning 101: 330-337.

van Herk, C. M., Aptroot, A. and van Dobben, H. F. 2002. Long-term monitoring in the Netherlands suggests that lichens respond to global warming. - The Lichenologist 34: 141-154.

Washburn, S. J. and Culley, T. M. 2006. Epiphytic macrolichens of the greater Cincinnati metropolitan area-Part II: distribution, diversity and urban mycology. - The Bryologist 109: 516-526. 


\section{FIGURES}
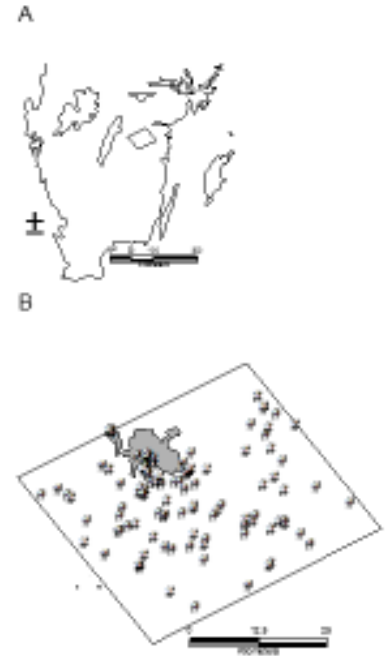

C

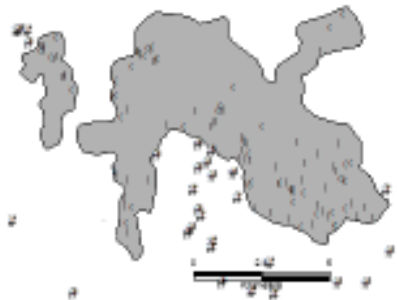

Figure 1. The study area location. A, Map of the southern parts of Sweden, where the diamond indicates the position of the survey area. B, Position of the rural oaks (triangles) around Linköping (grey). C, Urban (circles) and rural oaks (triangles) in and around Linköping (grey). 


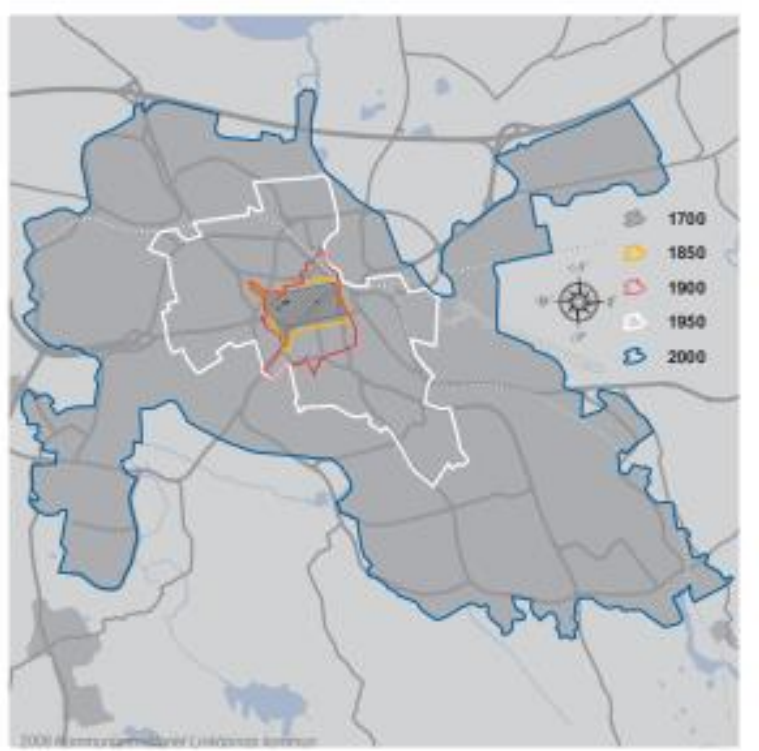

Figure 2. The concentric expansion of Linköping, SE Sweden, over the past 300 years. Reproduced with kind permission from the municipality of Linköping. 

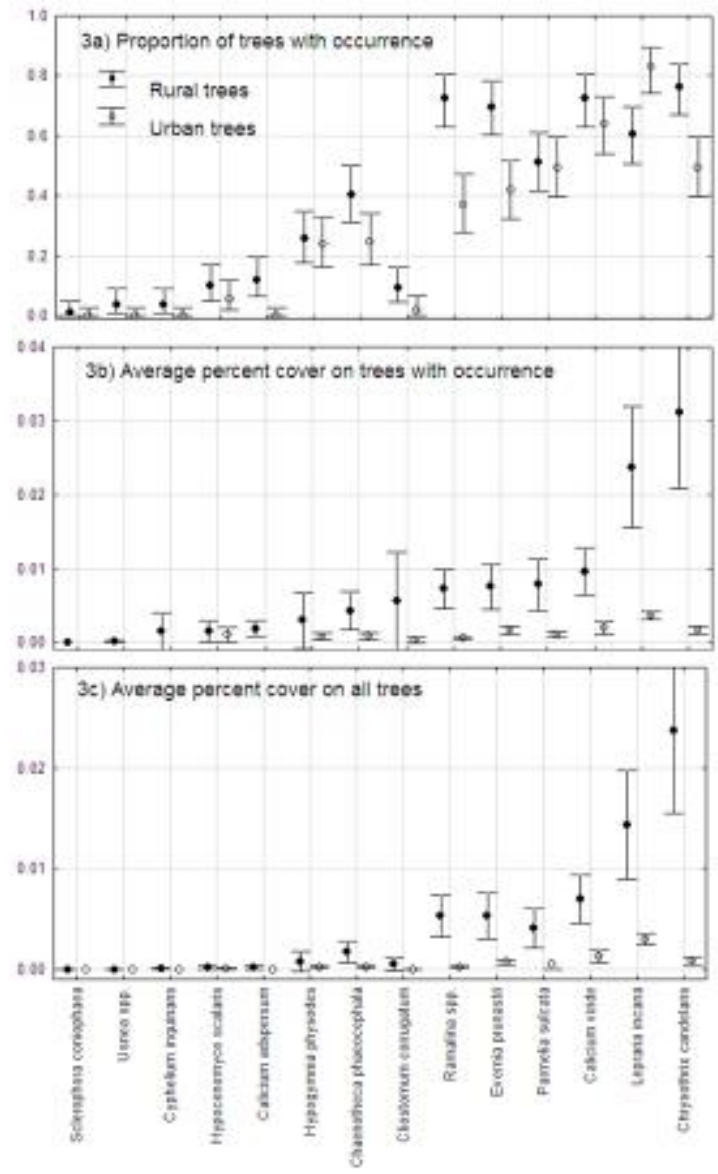

Figure 3. A comparison of the 14 investigated lichen species' occurrence and cover on oaks in urban and rural environments. A, shows the proportion of trees with occurrence. B, shows the average cover $(\%)$ on trees when present. $\mathrm{C}$, shows the average cover $(\%)$ based on all oaks. Error bars show 95\% confidence intervals (binomial ditto in A). Lines show the corresponding GLM solutions. 

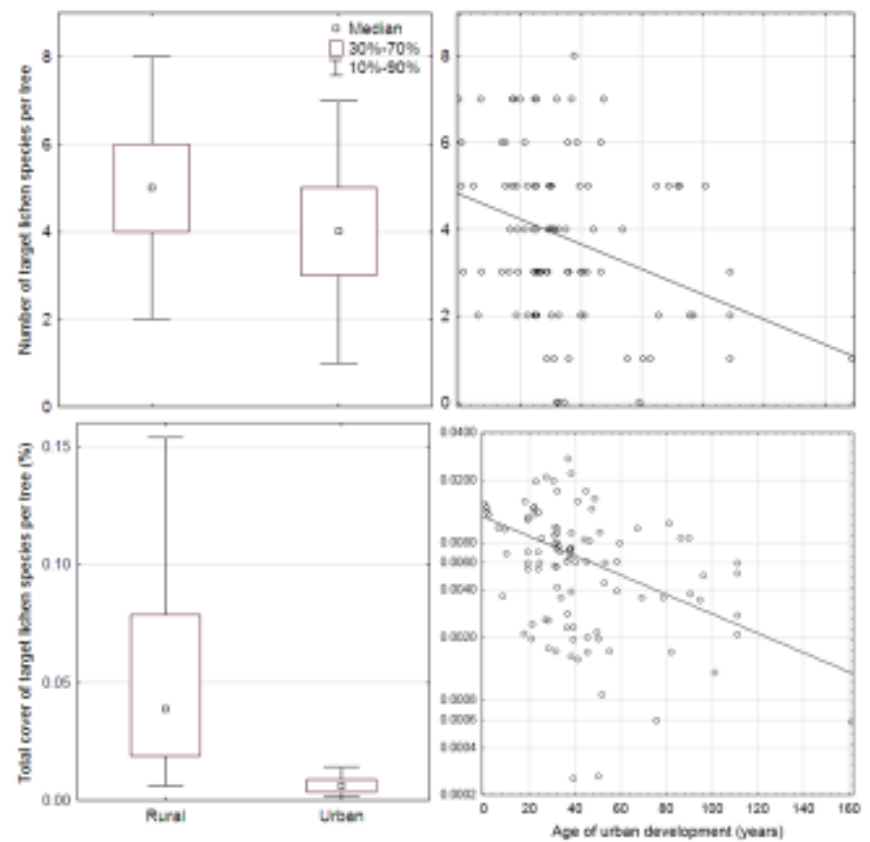

Figure 4. A and C, the median number of lichen species (of the 14 target species) and the percent of the trunks of Quercus robur covered by these lichens in rural and urban areas. In B and $\mathrm{D}$, the cover of target lichen species on urban oaks is shown as a function of when urbanization occurred (based on the average age of the five closest buildings). 

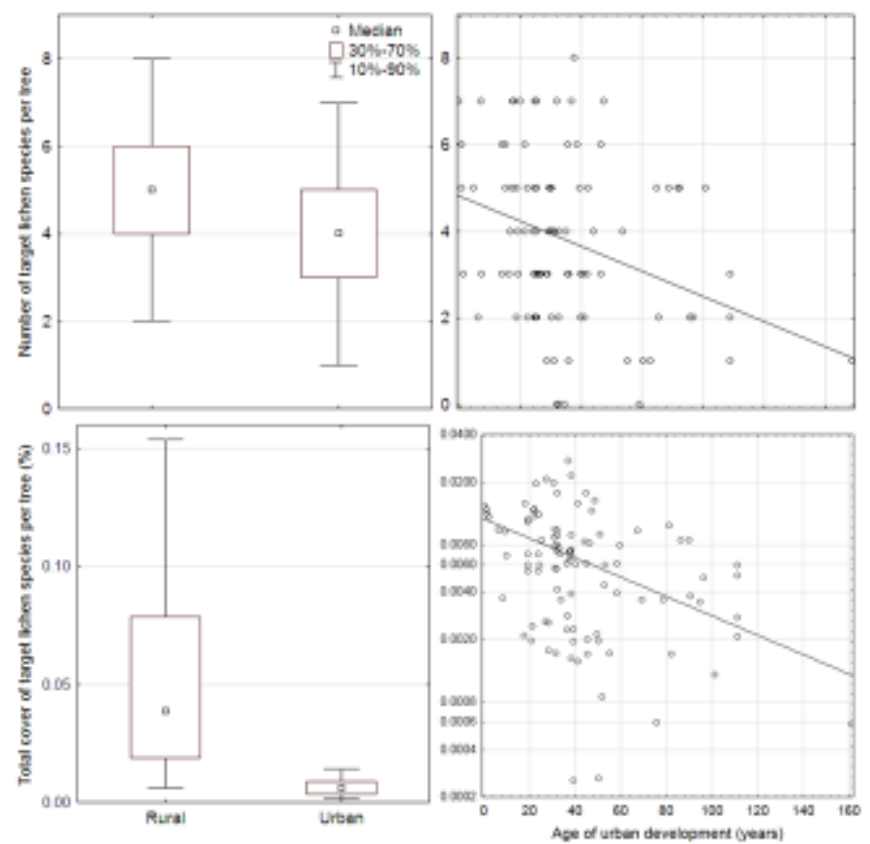

Figure 5. The predicted values based on results from a logistic regression of finding Calicium viride, Chrysothrix candelaris, Evernia prunastri and Ramalina spp. on trees in relation to the length_of urbanization. 
with varying substrate requirements

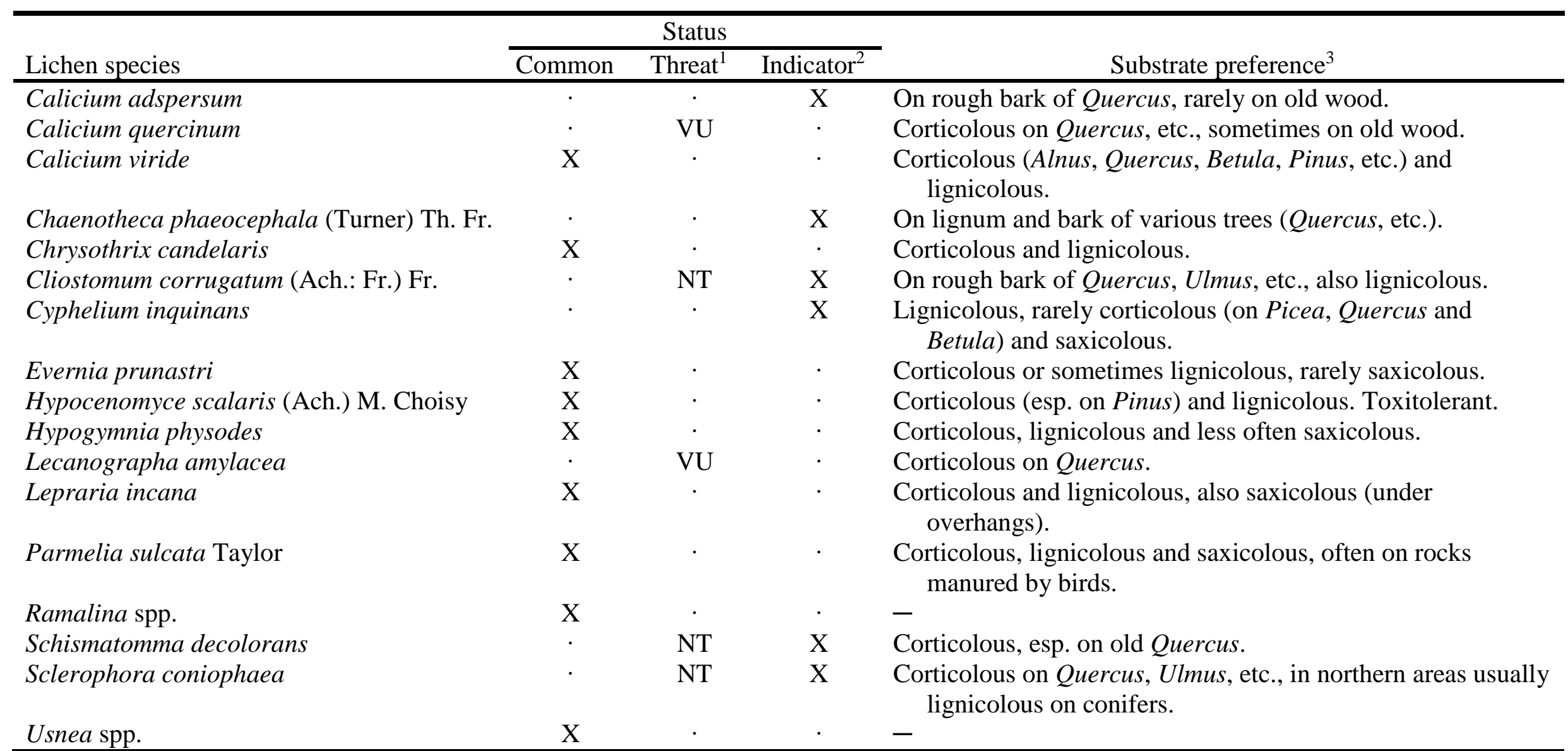

\section{${ }^{1}$ Gärdenfors (2005). VU = vulnerable; NT = near threatened}

${ }^{2}$ Nitare (2010).

${ }^{3}$ Santesson et al. (2004). 
Table 2. Characterisation of the urban and rural oak populations studied, and the explanatory variables used when modelling the occurrence of target lichens on Quercus robur in urban environments. The average depth of bark crevices is based on averages from each tree measured from the north, east, south and west. The summarised number of oak trees (including the focal tree) and summarised density of buildings; industrial area, high, low and enclosed buildings surrounding the focal tree on six different radius distances were calculated from a tree database and maps,

11 respectively

\begin{tabular}{|c|c|c|c|c|c|c|}
\hline & \multicolumn{3}{|c|}{ Urban $(n=105)$} & \multicolumn{3}{|c|}{ Rural $(n=109)$} \\
\hline & Average & Min & Max & Average & Min & $\operatorname{Max}$ \\
\hline Oaks circumference at breast height $(\mathrm{cm})$ & 341 & 230 & 574 & 351 & 250 & 530 \\
\hline Depth of bark crevices (mm) & $24 \cdot 8$ & $8 \cdot 8$ & $57 \cdot 5$ & $29 \cdot 2$ & $12 \cdot 6$ & $60 \cdot 0$ \\
\hline Sun exposure $(\%)$ & $36 \cdot 8$ & 0 & $63 \cdot 0$ & $32 \cdot 6$ & $4 \cdot 0$ & $60 \cdot 0$ \\
\hline \multicolumn{7}{|l|}{ Density of oaks $\left(\mathrm{ha}^{-1}\right)$ within: } \\
\hline $150 \mathrm{~m}$ & $0 \cdot 85$ & $0 \cdot 14$ & $3 \cdot 96$ & $0 \cdot 57$ & $0 \cdot 14$ & $2 \cdot 55$ \\
\hline $250 \mathrm{~m}$ & $0 \cdot 41$ & $0 \cdot 05$ & $1 \cdot 58$ & $0 \cdot 36$ & $0 \cdot 05$ & $1 \cdot 53$ \\
\hline $350 \mathrm{~m}$ & $0 \cdot 29$ & $0 \cdot 03$ & $1 \cdot 01$ & $0 \cdot 29$ & $0 \cdot 03$ & $1 \cdot 35$ \\
\hline $500 \mathrm{~m}$ & $0 \cdot 20$ & $0 \cdot 01$ & $0 \cdot 71$ & $0 \cdot 22$ & $0 \cdot 01$ & $1 \cdot 04$ \\
\hline $700 \mathrm{~m}$ & $0 \cdot 18$ & $0 \cdot 01$ & $0 \cdot 56$ & $0 \cdot 18$ & $0 \cdot 01$ & $0 \cdot 91$ \\
\hline $1000 \mathrm{~m}$ & $0 \cdot 13$ & $0 \cdot 02$ & $0 \cdot 36$ & $0 \cdot 15$ & $0 \cdot 00$ & $0 \cdot 71$ \\
\hline \multicolumn{7}{|l|}{ Area covered by buildings (\%) within: } \\
\hline $150 \mathrm{~m}$ & $35 \cdot 9$ & $0 \cdot 0$ & $88 \cdot 2$ & $0 \cdot 2$ & $0 \cdot 0$ & $15 \cdot 8$ \\
\hline $250 \mathrm{~m}$ & $39 \cdot 8$ & $0 \cdot 0$ & $78 \cdot 7$ & $0 \cdot 5$ & $0 \cdot 0$ & $24 \cdot 8$ \\
\hline $350 \mathrm{~m}$ & $40 \cdot 8$ & $0 \cdot 0$ & $77 \cdot 0$ & $0 \cdot 7$ & $0 \cdot 0$ & $28 \cdot 3$ \\
\hline $500 \mathrm{~m}$ & $40 \cdot 6$ & $5 \cdot 1$ & $71 \cdot 8$ & $0 \cdot 9$ & $0 \cdot 0$ & $35 \cdot 3$ \\
\hline $700 \mathrm{~m}$ & $38 \cdot 6$ & $7 \cdot 1$ & $75 \cdot 6$ & $1 \cdot 1$ & $0 \cdot 0$ & $30 \cdot 9$ \\
\hline $1000 \mathrm{~m}$ & $35 \cdot 8$ & $10 \cdot 4$ & $66 \cdot 3$ & $1 \cdot 4$ & $0 \cdot 0$ & $19 \cdot 8$ \\
\hline
\end{tabular}


17 indicate a positive or negative association with the response variables

\begin{tabular}{|c|c|c|c|c|c|c|c|c|}
\hline & $\begin{array}{c}\text { Hypogymnia } \\
\text { physodes }\end{array}$ & $\begin{array}{c}\text { Chaenotheca } \\
\text { phaeocephala }^{\mathrm{a}}\end{array}$ & $\begin{array}{l}\text { Ramalina } \\
\text { spp. }\end{array}$ & $\begin{array}{l}\text { Parmelia } \\
\text { sulcata } \\
\end{array}$ & $\begin{array}{c}\text { Evernia } \\
\text { prunastri }\end{array}$ & $\begin{array}{l}\text { Chrysothrix } \\
\text { candelaris }\end{array}$ & $\begin{array}{l}\text { Calicium } \\
\text { viride }\end{array}$ & $\begin{array}{c}\text { Lepraria } \\
\text { incana }\end{array}$ \\
\hline Length of urbanization & $0 \cdot 13-$ & $\cdot$ & $0 \cdot 013-$ & $\cdot$ & $0 \cdot 046-$ & $0 \cdot 0043-$ & $0 \cdot 0033-$ & $\cdot$ \\
\hline Tree circumference & $\cdot$ & $\cdot$ & $\cdot$ & . & $\cdot$ & $0 \cdot 0014+$ & $0 \cdot 069+$ & $0 \cdot 036+$ \\
\hline Bark crevices & $0 \cdot 14-$ & $0 \cdot 013+$ & . & . & . & $0 \cdot 061+$ & $0 \cdot 033+$ & . \\
\hline Sun exposure & $0 \cdot 12-$ & . & · & · & · & · & $0 \cdot 017-$ & $0 \cdot 022-$ \\
\hline \multicolumn{9}{|l|}{ Density of oaks within: } \\
\hline $150 \mathrm{~m}$ & $\cdot$ & $\cdot$ & . & $\cdot$ & $\cdot$ & . & $\cdot$ & $0 \cdot 16+$ \\
\hline $250 \mathrm{~m}$ & $\cdot$ & $\cdot$ & · & · & $0 \cdot 044-$ & $\cdot$ & · & $\cdot$ \\
\hline $350 \mathrm{~m}$ & $\cdot$ & $\cdot$ & · & $\cdot$ & $\cdot$ & $\cdot$ & · & $\cdot$ \\
\hline $500 \mathrm{~m}$ & $\cdot$ & $\cdot$ & $\cdot$ & . & . & . & · & · \\
\hline $700 \mathrm{~m}$ & $\cdot$ & $\cdot$ & · & · & $\cdot$ & $0 \cdot 099+$ & · & · \\
\hline $1000 \mathrm{~m}$ & · & · & · & · & · & $\cdot$ & · & · \\
\hline \multicolumn{9}{|l|}{ Area covered by buildings within: } \\
\hline $150 \mathrm{~m}$ & · & · & · & · & $\cdot$ & $\cdot$ & · & · \\
\hline $250 \mathrm{~m}$ & · & · & · & · & $\cdot$ & $\cdot$ & · & · \\
\hline $350 \mathrm{~m}$ & $0 \cdot 014+$ & $\cdot$ & · & · & $\cdot$ & $\cdot$ & $\cdot$ & $\cdot$ \\
\hline $500 \mathrm{~m}$ & $\cdot$ & · & · & $0 \cdot 039-$ & $\cdot$ & $\cdot$ & · & · \\
\hline $700 \mathrm{~m}$ & $\cdot$ & $\cdot$ & $0 \cdot 055-$ & $\cdot$ & $\cdot$ & $\cdot$ & · & · \\
\hline $1000 \mathrm{~m}$ & $\cdot$ & $0 \cdot 00076-$ & $\cdot$ & $\cdot$ & $\cdot$ & $\cdot$ & $\cdot$ & · \\
\hline P-value for the selected model & $0 \cdot 078$ & $0 \cdot 000043$ & $0 \cdot 00066$ & $0 \cdot 034$ & $0 \cdot 021$ & $<0 \cdot 00001$ & $0 \cdot 00007$ & $0 \cdot 0037$ \\
\hline
\end{tabular}


spores area, if pycnidium are present or not, the group to which the photobiont belongs and the growth form. The vegetative dispersal mode is

also indicated either by soredia or isidia

\begin{tabular}{lccccccc}
\hline Species & Cover $(\%)$ & Spores & Diaspores & Spore size $\left(\mu \mathrm{m}^{2}\right)$ & Pycnidium & Photobiont & Growth form \\
\hline Calicium adspersum & 0 & Yes & No & $82 \cdot 5$ & Yes & Trebouxia & Crustose \\
Cyphelium inquinans & 0 & Yes & No & 123 & Yes & Trebouxia & Crustose \\
Sclerophora coniophaea & 0 & Yes & No & $21 \cdot 6$ & No & Trentepohlia & Crustose \\
Usnea spp. & 0 & Rarely & Yes & $42 \cdot 4$ & No & Trebouxia? & Fruticose \\
Cliostomum corrugatum & $6 \cdot 66 \mathrm{E}-08$ & Yes & No & $23 \cdot 6$ & Yes & Trebouxia? & Crustose \\
Hypocenomyce scalaris & $5 \cdot 62 \mathrm{E}-07$ & Rarely & Yes & $20 \cdot 6$ & Rarely & Chlorococcus? & Crustose \\
Hypogymnia physodes & $1 \cdot 60 \mathrm{E}-06$ & Rarely & Yes & $29 \cdot 4$ & Yes & Trebouxia? & Foliose \\
Ramalina spp. & $2 \cdot 02 \mathrm{E}-06$ & Yes & Yes & $66 \cdot 3$ & Rarely & Trebouxia? & Fruticose \\
Chaenotheca phaeocephala & $2 \cdot 22 \mathrm{E}-06$ & Yes & No & $33 \cdot 2$ & No & Trebouxia & Crustose \\
Parmelia sulcata & $4 \cdot 75 \mathrm{E}-06$ & Rarely & Yes & $68 \cdot 7$ & Rarely & Trebouxia? & Foliose \\
Evernia prunastri & $6 \cdot 14 \mathrm{E}-06$ & No & Yes & - & No & Trebouxia? & Fruticose \\
Chrysothrix candelaris & $8 \cdot 41 \mathrm{E}-06$ & No & Yes & - & No & Green algae & Crustose \\
Calicium viride & $1 \cdot 19 \mathrm{E}-05$ & Yes & No & $63 \cdot 8$ & No & Trebouxia & Crustose \\
Lepraria incana & $2 \cdot 89 \mathrm{E}-05$ & No & Yes & - & No & Trebouxia? & Crustose \\
P-value & - & 0.039 & $0 \cdot 19$ & 0.95 & $0 \cdot 16$ & NA & $0 \cdot 27$ \\
\hline
\end{tabular}

